\title{
ISOLATION AND SEQUENCING OF MRF4 GENE (EXON 1 THROUGH 4) FROM EGYPTIAN BUFFALO
}

\author{
Abbas ,H.E. ${ }^{a}$, El- kattawy, A.M. ${ }^{a}$ Mokhbatly, A. A.M. ${ }^{b}$ and Abu El-Magd, \\ M.E.R. ${ }^{c}$ \\ ${ }^{a}$ Department of biochemistry, Fac. of Vet. Med. Kafr elsheikh Univ., Egypt. \\ ${ }^{\mathrm{b}}$ Department of clinical pathology, Fac. of Vet. Med. Kafr elsheikh Univ., Egypt. \\ ${ }^{c}$ Department of Anatomy and Embryology, Fac. of Vet. Med. Kafr elsheikh Univ., Egypt.
}

\begin{abstract}
Muscle regulatory factor 4(MRF4, also known as herculin and MYF6) is a member of MyoD family, which is involved in the differentiation and maturation of myotubes and highly expressed postnatally.The sequences of this gene are well known in cattle and small ruminants but in buffalo no available sequence was previously recorded before this research. Therefore, the main aim of this study is to isolate and sequence exon 1 (E1) through exon 4 (E4) portion of this gene, which is the most appropriate portion of MRF4 that contains single nucleotide polymorphisms (SNPS), in buffalo. To achieve this, RT$P C R$ was performed in which gene-specific primers flanking to E1-E4 of MRF4 were utilized in addition to PCR master mix. A PCR product of 693bp, of MRF4 gene corresponding to the expected theoretical product size, was successfully amplified. Sequencing of the purified PCR product and its alignment against a previously known bovine gene identified 4 synonymous novel SNPs in buffalo MRF4. This result indicates that the sequence of MRF4 is highly conserved between cattle and buffalo. This is a preliminary study that provides the researchers withraw data which could be used as a basis for further studies to associate these SNPs with meat quality traits in buffalo.
\end{abstract}


Keywords: muscle regulatory factor 4, sequencing, RT-PCR

\section{INTRODUCTION}

Myogenesis (meat synthesis) is mainly controlled by genes of myogenic regulatory factors (MRFs) family, which comprises four structurally and functionally related genes: myogenic differentiation 1 (MYOD1), myogenin (MYOG), myogenic regulatory factor 5 (MYF5) and myogenic regulatory factor 4 (MRF4, also called herculin/MYF6) (Olson et al.,1991 and Weintraubet al.,1991). These genes regulate the balance between proliferation and differentiation of primary muscle cells (Kitzmann and Fernandez., 2001) andplay a vital role in determination and development of muscle tissue (Gerhard and Grant.,2003).

MRF4 gene acts as a determining factor in the absence of MYF5 and MYOD1 during the onset of myogenesis. It is also a gene that is postnatally expressed at a level about 10 times higher than the other genes of the MRFs family and therefore is supposed to play a role in the maintenance of the skeletal muscle phenotype and is considered as candidate gene for growth related traits in meat-producing animal species (Mehmetet al.,2012).

MRF4 polymorphism is important for the myotube fusion, maturation and maintenance of the skeletal muscle weight (Wysznskaet al.,2006). Nucleotide sequence polymorphisms were identified in MRF4 gene in exon 1 through 4 which is connected with carcass meat and fat deposition trait (Barbara., 2008).

The a forementioned research works have been done on exon 1 through 4 of MRF4 but on animals other than buffalo. Therefore we aimed from this work to identify the sequences of MRF4 (exon 1 through 
4) and to record any possible single nucleotide polymorphisms (SNPs).

\section{MATERIALS AND METHODS}

\section{Sampling and RNA extraction:}

The study involved 50 pure Egyptian water buffalo-bulls (Bubalus bubalis) kept on a farm located inNucleus Herd,Nataff Gedeed station of Mahalet Mousa farm,Kafr El Sheikh Governorate.Tissues samples were collected from buffalo gluteal muscles using biopsy needle gauge 18.RNA.The controlled tissue samples were extracted using total RNA Purification Kit following the manufacturer protocol (Fermentas, \# K 0731).

\section{RT-PCR:}

First, reverse transcription technique was performed using Revert Aid H minus Reverse Transcriptase (Fermentas, \#EP0451), which is a genetically modified M-MuLV RT, to convert RNA into complementary DNA (cDNA). The PCR primers were designed using Primer 3 software.The isolated cDNA was amplified using primers and PCR master mix kit following the manufacturer protocol (Fermentas, \#K1071). The PCR reaction was carried out in a gradient PCR (TC-plus, Techne, UK)following these steps: initial denaturation at $94^{\circ} \mathrm{C}$ for $5 \mathrm{~min}$ followed by 35 cycles of $94^{\circ} \mathrm{C}$ for $30 \mathrm{sec}$ for DNA denaturation, annealing temperatures $55^{\circ} \mathrm{C}$ for $1 \mathrm{~min}$, extension at $72{ }^{\circ} \mathrm{C}$ for $1 \mathrm{~min}$ and 
final extension at $72{ }^{\circ} \mathrm{C}$ for $5 \mathrm{~min}$.

Primer sequences and PCR product characteristics are given in the table below:

\begin{tabular}{|c|c|c|c|c|c|}
\hline Gene & $\begin{array}{c}\text { Forward primer } \\
\left({ }^{\prime} 5-/ 3\right)\end{array}$ & $\begin{array}{c}\text { Reverseprimer } \\
((5-/ 3)\end{array}$ & $\begin{array}{l}\text { Ta* } \\
\left({ }^{\circ} \mathbf{C}\right)\end{array}$ & $\begin{array}{l}\text { Size } \\
\text { (bp) }\end{array}$ & $\begin{array}{l}\text { Localizat } \\
\text { ion }\end{array}$ \\
\hline MRF4 & $\begin{array}{c}\text { CCTTTTTGAAACTGGCT } \\
\text { CCT }\end{array}$ & $\begin{array}{c}\text { CAGGGGAGTTTGTGTTC } \\
\text { CTC }\end{array}$ & 55 & 693 & $\begin{array}{l}\text { Exon } \\
1-4\end{array}$ \\
\hline
\end{tabular}

* Ta = annealing temperature

\section{Gel Electrophoresis:}

Gel electrophoresis was performed to detect the integrity of RNA fragments after RNA extraction and DNA fragments after PCR reaction using TAE Electrophoresis Buffer (Bioshop, 1L22854), 1\% Agarose (bioshop, 1L22739), (100 bp ladder DNA marker) (Fermentas, \#SM0321) and DNA loading buffer, 6x.

\section{PCR purification:}

After getting PCR products with expected size, the clone was purified using PCR purification kit following the manufacturer protocol (Jena Bioscience \# pp-201 $\times \mathbf{s}$ ) toremove primer dimmers, primers, nucleotides, proteins, salt, agarose, ethidium bromide and other impurities.

\section{DNA Sequencing:}

The PCR products were sequenced in automated sequencer (Applied Biosystem, USA). The Sequences were analyzed using the Chromas Lite 2.1program (http://technelysium.com.au/?page_id=13) and the identity of the sequenced PCR product was examined using Blast search against Genbank database of cattle (Bos Taurus) (http://blast.ncbi. nlm.nih.gov/Blast.cgi).The alignment was performed using Clustal W 
method in Geneious 4.8.4software (http://www.geneious.com/web/ geneious /home).

\section{RESULTS}

In this work, we employed the power of the PCR technique in order to isolate a portion of MRF4 gene from Egyptian buffalo. We first isolated RNA from muscular tissue. The prepared RNA was ofhigh quality as its two ribosomal bands were practically free of any degradation as judgedby gel electrophoresis (figure 1).Prior to PCR, the RT reaction containing synthesized cDNA was performed and gene specific primers (Table1) were designed for the subsequent PCR step to amplify the desired gene. The PCR product with the expected size (693bp) was obtained as shown by $1 \%$ agarose gel electrophoresis photo (figure 2). Then, the resulting PCR products were purified. Subsequently, sequencing was carried out in order to verify the identity of the PCR product and to detect any SNPs.

The obtained sequence was examined against previously known sequences published in GenBank database using Blast search. The results of this step confirmed that,the sequence as expected is identical to abovine MRF4 (Bostaurus accession no. AB110601) except in four positions. These four SNPs were a T/C transition at position 25, a G/A transition at position 70, a $\mathrm{C} / \mathrm{T}$ transition at position 160 and a $\mathrm{C} / \mathrm{A}$ transition at position 262 (Figures, 3-6).All the previous transitions were 
synonymous, since they didnot change the amino acid sequence in MRF4 protein.

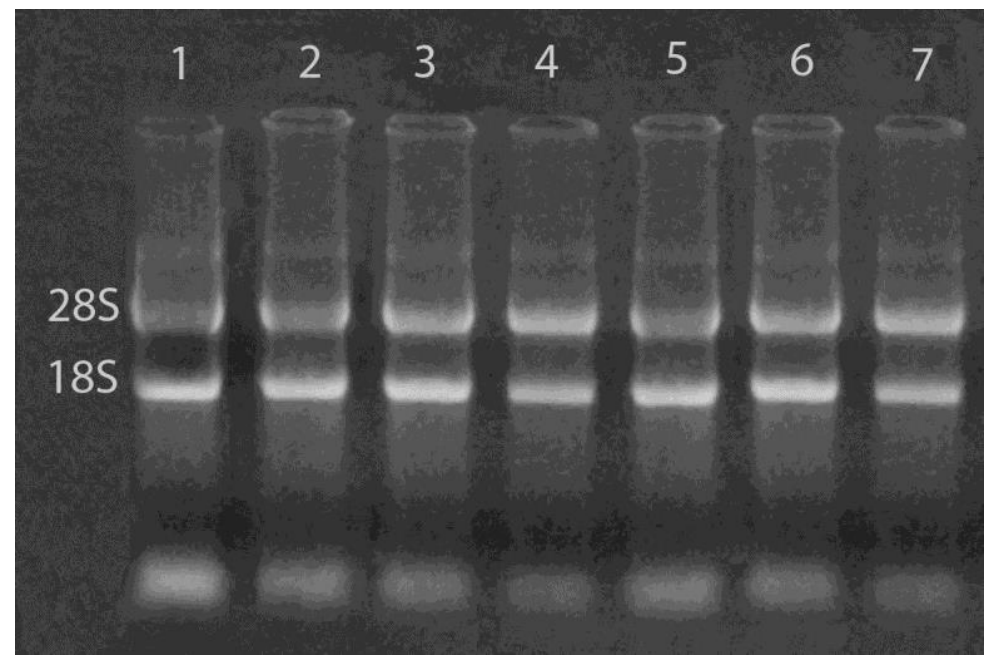

Fig. (1): Ethiduim bromide stained agarose gel showing extracted RNA from skeletal muscle taken from Egyptian buffaloes, each lane contains ribosomal RNA with its intact two bands:18s and 28s.

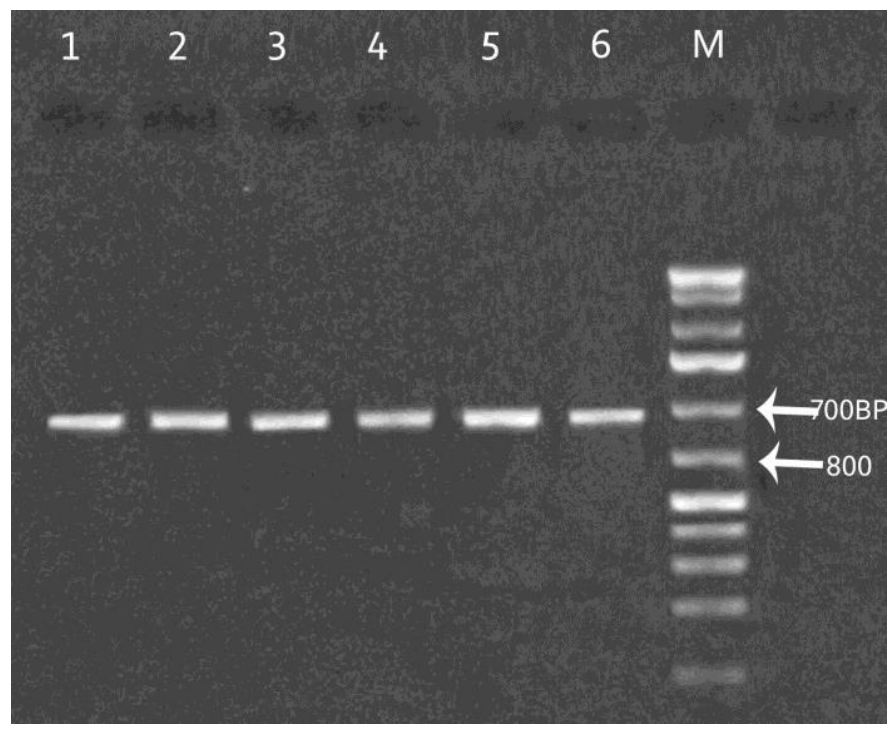




Fig. (2): Ethiduim bromide stained agarose gel showing amplified 693bp PCR products of MRF4gene taken from 6 animals (from lane 1-6), and $\mathrm{M}$ indicate $100 \mathrm{bp}$ ladder.

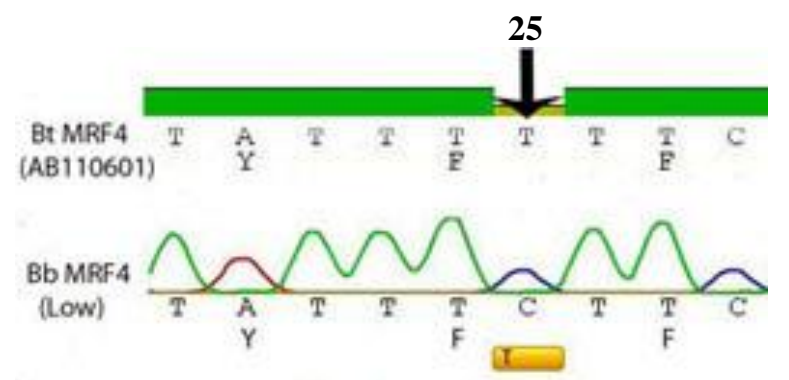

Fig. (3): T/C transition at position 25 in MRF4 gene of Egyptian buffalo.

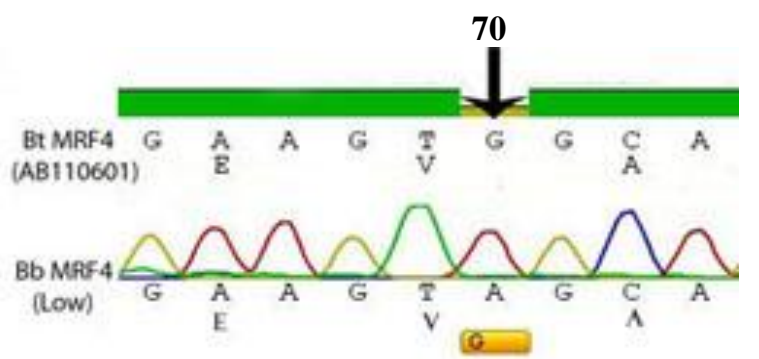

Fig. (4): G/A transition at position 70 in MRF4 gene of Egyptian buffalo.

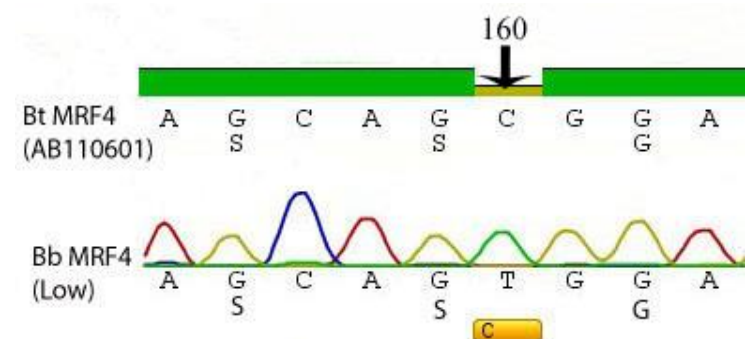

Fig. (5): a G/T transition at position 160 in MRF4 gene in Egyptian buffalo 


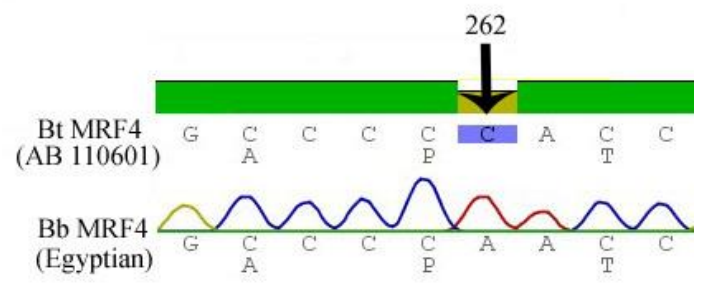

Fig. (6): a C/A transition at position 262in MRF4 gene in egypian buffalo

\section{DISCUSSION}

The postnatal muscle growth and differentiation is characterized by many cellular and metabolic events related to myogenesis (meat synthesis) and controlled by different genes (Pierzchataet al.,2011). These myogenic genes are considered as candidate genes for meat production traits (Te Pas et al.,1999, Wysznskaet al.,2006, Verner et al.,2007). MRF4 gene is supposed to play a role in the maintenance of the skeletal muscle phenotype as it is postnatally expressed at a level about 10 times higher than other members of MRFs family. Therefore, it is considered as candidate gene for growth related traits in meatproducing animal species (Barbara et al., 2012). In bovine, MRF4 gene exhibits a number of polymorphisms, which have associations with growth, or carcass and meat quality traits (Urbanskiet al.,2006). For example, a significant correlation between the MRF4 polymorphism and carcass weight was identified (Wysznskaet al.,2006). The a forementioned research works have been done on exon 1 through 4 of MRF4 but on animals other than buffalo. Therefore we aimed from this work to identify the sequences of MRF4 (exon 1 through 4) and to record any possible SNPs.

Comparing to bovine MRF4, we have found four SNPs as the following: a T/C transition at position 25 , a G/A transition at position 70 , a C/T transition at position 160 and a C/A transition at position 262.All 
the previous transitions were synonymous, since they did not change the amino acid sequence in MRF4 protein.

This result indicates that the sequence of MRF4 is highly conserved between cattle and buffalo. This is a preliminary study that provides the researchers with raw data can be used as a basis for further research to associate these SNPs with meat production and quality traits in buffalo (this is our current work).

\section{ACKNOWLEDGEMENT}

The authors are thankful to doctor Mohamed El Saed Rezk El Ghanam, manager of biotechnology research center, Faculty of Veterinary medicine, Kafr El Skeikh University, for providing all necessary facilities to carry out the work.

\section{REFERENCE}

- Barbara Rejduch, Genes associated with production and health in farm animals, 2008, central europian agriculture journal, Volume 9 No. 4 (829-836) 829.

- Gerrard, D. E., and A. L. Grant, Principles of Animal Growth \&Development,2003, Kendall/Hunt Publishing Co. Dubuque, 1A.

- KITZMANN M., FERNANDEZ A., Crosstalk between cell cycle regulators and the myogenic factor MyoD in skeletal myoblasts, 2001,Cellular and Molecular Life Sciences 58, 571-579.

- Mehmet Ulaş ÇINAR, Huitao FAN, Christiane NEUHOFF , Christine GROßE-BRINKHAUS, eQTL Analysis and Association of MYF6 mRNA Expression with Meat Quality Traits in Pigs, 2012,RESEARCH ARTICLE 18 (2): 235-242.

- OLSON E.N., BRENNAN T.J., CHAKRABORTY T., CHENG T.C., 
CSERJESI P., EDMONDSON D., JAMES G., LI L., Molecular control of myogenesis antagonism between growth and differentiation,1991, Molecular and Cellular Biochemistry 104, 7-13.

- PIERZCHALA M., PAREEK C.S., LISOWSKI P., URBAŃSKI P., GOLUCH D., KAMYCZEK M., ROŻYCKI M., COOPER R.G., KURYL J., Evaluation based selection of reference genes for porcine hepatic tissue, 2011,Animal Science Papers and Reports 29, 53-63

- TE PAS M.F., SOUMILLION A., HARDERS F.L., VERBURG F.J., VAN DEN BOSCH T.J., GALESLOOT P., MEUWISSEN $\boldsymbol{T} . \boldsymbol{H}$., Influences of myogenin genotypes on birth weight, growth rate, carcass weight, backfat thickness and lean weight of pigs,1999. Journal of Animal Science77, 2352-2356.

- URBAŃSKI P., FLISIKOWSKI K., STARZYNSKI R., KURYE J., KAMYCZEK K., A new SNP in the promoter region of the porcine MYF5 gene has no effect on its transcript level in $\mathrm{m}$. longissimus dorsi,2006,Journal of Applied Genetics 47, 59-61.

- VERNER J., HUMPOLICEK P., KNOLL A., Impact of MYOD family genes on pork traits in Large White and Landrace pigs,2007,Journal of Animal Breeding and Genetics 124, 81-85.

- WEINTRAUB H.R., DAVIS S., TAPSCOTT M., THAYER M., KRAUSE R., BENEZRA T.K., BLACKWELL D., TURNER R., RUPP S., HOLLENBERG Y., LASSAR A., The MyoD gene family Nodal point during specification of the muscle cell lineage, 1991,Science 251, 761-766. 
- WYSZYNSKA-KOKO J., PIERZCHALA M., FLISIKOWSKI K., KAMYCZEK M., ROZYCKI M., KURYL J., Polymorphisms in coding and regulatory regions of the porcine MYF6 and MYOG genes and expression of the MYF6 gene in m. longissimus dorsi versus productive traits in pigs,2006 ,Journal of Applied Genetics 47, 131138.

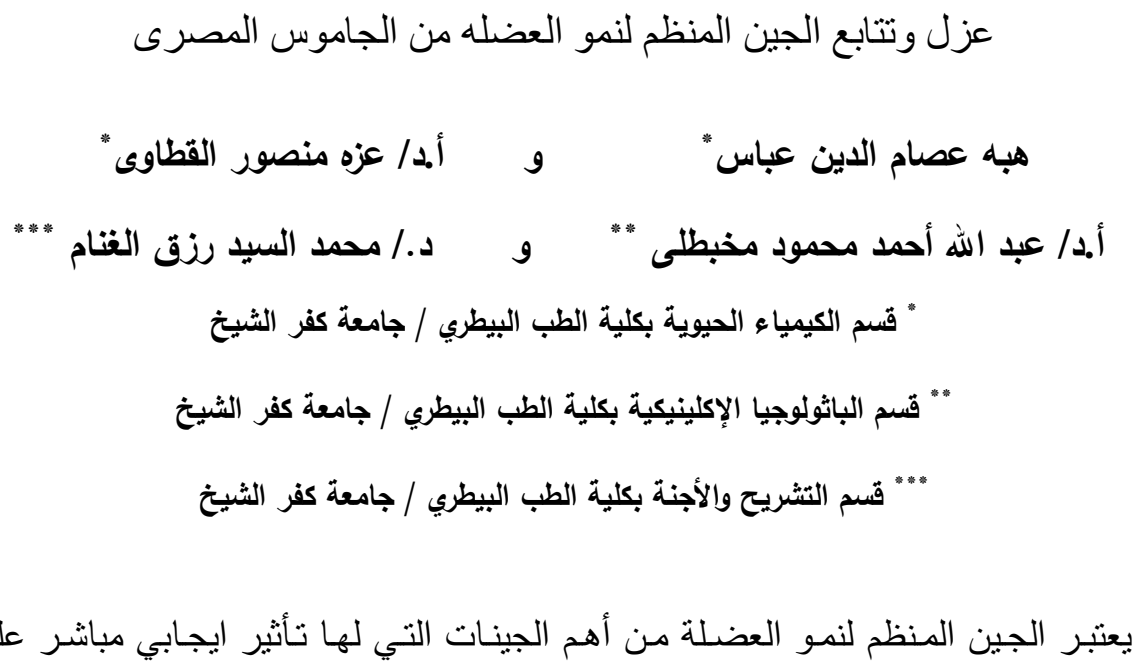

بعتبر الجين المنظم لنمو العضلة من أهم الجينات التي لها تأثثر ايجابي مباثر على نمو

العضلة قبل وبعد الولادة لذا فقد نركز الاهتمام فى هذا العمل على دراسة هذا الجين بغية الاستفادة منه في تحسين إنتاج سلالات الجاموس المصري، حيث تركزت الدراسة على التعرف على هذا الجين من خلال فصل الحمض النووي الريبوزومى الكلى (RNA) من النسيج العضلي كعضو أساسي لتواجد هذا الجين ثم إجراء عملية النسخ العكسي (Reverse transcription) بغية الحصول على التسلسل المقابل من الحامض النووي دى أوكسى ريبوزCDNA ثم عمل ثقنية تفاعل البلمرة المتسلسل (PCR) عن طريـق اختيار البادءات الخاصـة بهذا الجين، وقد أظهرت النتائج أن الحجم الناتج عن تفاعل 
البلمرة المتسلسل هو 693 زوج من النيوكلوتيدات وبعد التتقيـة وعمل تتابع نيوكلوتيدى لها أظهرت

النتائج وجود 4 طفرات جينية وحيث أن هذا العمل يعتبر الأول من نوعه لعزل هذا الجين في الجاموس المصري لهذا فقد تم مقارنة التتابع الجيني بتتابعات جينية لأنواع أخرى من المانشية. 